https://doi.org/10.18778/1509-877X.2021.01.04

\title{
Glosa do postanowienia Sądu Najwyższego Z DNIA 15 STYCZNIA 2021 ROKU, SYGN. III KK $321 / 19$
}

Streszczenie: Komentarz do orzeczenia Sądu Najwyższego dotyczącego czynu karnoskarbowego - tzw. nieodprowadzenia w terminie przez płatnika pobranego podatku (art. $77 \S 1$ k.k.s.). Autor aprobuje stanowisko Sądu Najwyższego potwierdzające, że wskazany czyn karnoskarbowy ma tzw. charakter materialny. Ponadto koncentruje się na problemie bezzasadnego ścigania karnego w sprawach podatkowych. Słowa kluczowe: podatki, Kodeks karny skarbowy, nieodprowadzenia w terminie przez płatnika pobranego podatku, materialny charakter czynu podatkowego

1. Teza komentowanego judykatu zasługuje na aprobatę. Brzmi ona następująco: „Nie można skutecznie zarzucić «rażącego naruszenia prawa materialnego» w sytuacji, gdy sąd to prawo stosując, odwołuje się do jednoznacznie przyjętej w doktrynie i orzecznictwie wykładni. [...] Czyn zabroniony z art. 77 k.k.s. ma charakter materialny, a to ze względu na definicję legalną zawartego w nim znamienia «nie wpłaca» z art. $53 \$ 29$ w zw. z $\$ 27$ k.k.s.”

* Doktor habilitowany nauk prawnych, profesor Uniwersytetu Łódzkiego, Katedra Postępowania Karnego i Kryminalistyki, Wydział Prawa i Administracji, e-mail: jizydorczyk@ wpia.uni.lodz.pl, https://orcid.org/0000-0001-7275-8150 
2. Zgodnie $z$ aktualną treścią przepisu art. $77 \S 1$ Kodeksu karnego skarbowego $^{1}$ (czyn skarbowy tzw. nieodprowadzenia $\mathrm{w}$ terminie przez płatnika pobranego podatku - zmodyfikowany odpowiednik dawnego przepisu art. 98 ustawy o komornikach sądowych ${ }^{2}$ ) płatnik lub inkasent, który pobranego podatku nie wpłaca $\mathrm{w}$ terminie na rzecz właściwego organu, podlega karze 3 . Dawniej zaś (do 2005 r.) przepis ten miał brzmienie następujące: płatnik lub inkasent, który pobranego podatku nie wpłaca $\mathrm{w}$ terminie na rachunek właściwego organu. Prawnym uzasadnieniem (ratio legis) tej regulacji jest penalizowanie samego nieodprowadzenia $\mathrm{w}$ terminie pobranych od podatnika kwot podatku ${ }^{5}$.

Na gruncie przedmiotowej sprawy - którą ostatecznie zajął się Sąd Najwyższy - chodziło o zarzuty karne oparte na tym, że osoba odpowiedzialna za terminowe wywiązywanie się ze zobowiązań podatkowych - płatnik podatku dochodowego od osób fizycznych, wbrew art. 38 ust. 1 Ustawy z dnia 26 lipca 1991 r. o podatku dochodowym od osób fizycznych ${ }^{6}$ - nie wpłacała w terminie ustawowym (tzn. do 20. dnia miesiąca następującego po miesiącu, w którym pobrano zaliczkę) na rachunek właściwego urzędu skarbowego pobranych zaliczek na podatek dochodowy od osób fizycznych z tytułu wypłaconych wynagrodzeń za określone miesiące. W I instancji właściwy sąd rejonowy częściowo uniewinnił oskarżonego; następnie apelację od tego wyroku wniosła zarówno obrona, jak i oskarżenie (prokurator). W następstwie wniesionych apelacji właściwy sąd okręgowy zmienił zaskarżony wyrok (jednak jeszcze bardziej go łagodząc). W konsekwencji prokurator wniósł kasację do Sądu Najwyższego, w której zarzucił „rażące i mające istotny wpływ na treść orzeczenia naruszenie przepisów prawa materialnego, tj. art. $76 \$ 1$ ustawy z dnia 29 sierpnia 1997 r. Ordynacja podatkowa poprzez niezasadne przyjęcie, że zarachowanie nadpłaty na poczet zaległości podatkowych w sytuacji, kiedy nadpłata powstała wcześniej niż zaległość podatkowa, następuje z mocy prawa $\mathrm{z}$ chwilą wymagalności zaległości podatkowej, co skutkowało

1 Ustawa z dnia 10 września 1999 r. - Kodeks karny skarbowy (tekst jedn. Dz.U. z 2021 r., poz. 408), dalej: k.k.s.

${ }^{2}$ Ustawa z dnia 22 marca 2018 r. o komornikach sądowych (tekst jedn. Dz.U. z 2021 r., poz. 850),

3 T. Grzegorczyk, Kodeks karny skarbowy. Komentarz, wyd. 4, Kraków 2009, s. 366-367.

${ }^{4}$ Ibidem.

${ }^{5}$ Ibidem, s. 366.

6 Tekst jedn. Dz.U. z 2010 r., Nr 51, poz. 307. 
uznaniem, iż czyny zarzucane oskarżonemu nie wyczerpały znamion art. 77 $\$ 1$ k.k.s. w zw. z art. $6 \$ 2$ k.k.s. w zw. z art. $9 \$ 3$ k.k.s.".

W wyniku rozpoznania sprawy Sąd Najwyższy uznał kasację za oczywiście bezzasadną, lecz pomimo to sporządził uzasadnienie, odnosząc się do najistotniejszych motywów swojego rozstrzygnięcia. W uzasadnieniu do postanowienia Sąd Najwyższy przypomniał m.in., że zgodnie z art. 76 $\$ 1$ Ustawy z dnia 29 sierpnia 1997 r. - Ordynacja podatkowa nadpłaty podatku wraz $\mathrm{z}$ ich oprocentowaniem podlegają zaliczeniu $\mathrm{z}$ urzędu na poczet zaległości podatkowych wraz z odsetkami za zwłokę, odsetek za zwłokę od nieuregulowanych w terminie zaliczek na podatek, kosztów upomnienia oraz bieżących zobowiązań podatkowych, a w razie ich braku podlegają zwrotowi z urzędu, chyba że podatnik złoży wniosek o zaliczenie nadpłaty w całości lub w części na poczet przyszłych zobowiązań podatkowych ${ }^{8}$.

Tymczasem zdaniem oskarżenia (prokuratora) wskazany przepis Ordynacji podatkowej powinien być rozumiany dosłownie, a więc tak, że wystąpienie nadpłaty nie daje organowi podatkowemu pełnej swobody w dysponowaniu nią i tym samym taką nadpłatę organ podatkowy powinien zaliczyć na poczet zaległości podatkowych, odsetek lub bieżących zobowiązań - zaliczenie jej zaś na poczet przyszłych zobowiązań podatkowych jest możliwe tylko na wniosek podatnika. W przypadku gdy podatnik takiego wniosku nie złoży, nadpłata podatku powinna zostać mu z urzędu zwrócona. Tym samym (zdaniem prokuratora) nie istnieje podstawa prawna do zaliczenia nadpłaty na poczet zaległości podatkowych powstałych po dniu jej wystąpienia ${ }^{9}$.

Na tle takiego stanu faktycznego Sąd Najwyższy zasadnie uznał, że pogląd prokuratora jest całkowicie błędny. Przede wszystkim ze względu na to, że właściwy Sąd Okręgowy w swoim wyroku odwołał się do ugruntowanego już orzecznictwa sądów administracyjnych (w tym poglądów zawartych w judykatach Naczelnego Sądu Administracyjnego ${ }^{10}$ ), zgodnie z którym możliwe jest zaliczenie nadpłaty na poczet zaległości podatkowych także w sytuacji, kiedy nadpłata powstała wcześniej niż zaległość podatkowa, i wówczas z mocy prawa takie zaliczenie dokonuje się z chwilą wymagalności zaległości podatkowej. Tym samym - słusznym zdaniem Sądu Najwyższego - nie mogło w przedmiotowej sprawie zachodzić tzw. rażące

\footnotetext{
7 Zob. uzasadnienie do glosowanego postanowienia Sądu Najwyższego.

8 Ibidem.

9 Ibidem.

10 Zob. cytowane w uzasadnieniu postanowienia orzeczenia sądów administracyjnych.
} 
naruszenie prawa materialnego (w rozumieniu przepisów Kodeksu postępowania karnego $\left.{ }^{11}\right)^{12}$. Ponadto Sąd przypomniał, że czyn skarbowy penali-zowany w art. 77 k.k.s. ma charakter materialny z tego względu, że znamię w postaci „nie wpłaca” jest definiowane ustawowo (tzw. definicja legalna) w przepisach art. $53 \$ 29$ k.k.s. i art. $53 \$ 27$ k.k.s. ${ }^{13}$ Zgodnie z treścią tych definicji należność publicznoprawna uszczuplona czynem zabronionym to wyrażona liczbowo kwota pieniężna, od której uiszczenia lub zadeklarowania uiszczenia w całości lub w części osoba zobowiązana uchyliła się i w rzeczywistości ten uszczerbek finansowy nastąpił (art. 53 $\$ 27$ k.k.s.), oraz przepis ten stosuje się odpowiednio do następujących określeń: „kwota niewpłaconego podatku”, „nienależny zwrot należności celnej lub umorzenie należności celnej należnej do zapłacenia”, „nienależny zwrot należności podatkowej”, „nie pobiera podatku”, „nie wpłaca w terminie podatku”, "pobrany podatek”, „pobranego podatku nie wpłaca”, „podatek” oraz „wypłata lub pobranie nienależnej, nadmiernej lub wykorzystanej niezgodnie z przeznaczeniem dotacji lub subwencji" (art. $53 \$ 29$ k.k.s.) ${ }^{14}$. Ponadto Sąd Najwyższy trafnie przypomniał, że przestępstwo skarbowe z przepisu art. $77 \$ 1$ k.k.s. nie jest (jak było to określone do czasu nowelizacji Kodeksu karnego skarbowego z 2005 r.) tzw. przestępstwem formalnym. Co więcej, skoro nie wpłacano stosownych kwot $\mathrm{z}$ tytułu podatku od wynagrodzeń pracowniczych $\mathrm{w}$ terminie, mając jednak wcześniej tego podatku nadpłatę z mocy prawa zaliczaną na poczet powstałych zaległości, to w sposób oczywisty nie mogło skutkiem takiego działania być powstanie uszczerbku finansowego w rozu-mieniu definicji legalnej z art. $53 \$ 27$ k.k.s. I jeszcze na koniec (co podkreśla się w glosowanym judykacie): nawet gdyby rzeczywiście przestępstwa zarzucane temu konkretnemu oskarżonemu były przestępstwami o tzw. charakterze formalnym, to przecież, w ustalonych w tej konkretnej sprawie okolicznościach faktycznych, ich szkodliwość społeczna byłaby co najwyżej znikoma (sic!) ${ }^{15}$. Jak widać, w tej sprawie organy

11 Ustawa z dnia 6 czerwca 1997 r. - Kodeks postępowania karnego (tekst jedn. Dz.U. z 2021 r., poz. 534),

12 Zob. uzasadnienie do glosowanego postanowienia Sądu Najwyższego.

13 Zob. też P. Kardas, G. Łabuda, T. Razowski, Kodeks karny skarbowy. Komentarz, wyd. 3, Warszawa 2017, komentarz do art. 77 k.k.s.

14 Zob. T. Grzegorczyk, Kodeks karny skarbowy..., s. 226-228.

15 Ibidem, s. 33. Zob. przepis art. $1 \$ 2$ k.k.s., zgodnie z którym nie jest przestępstwem skarbowym lub wykroczeniem skarbowym czyn zabroniony, którego społeczna szkodliwość jest znikoma. 
państwowe bardziej brały pod uwagę ściganie czynów karnoskarbowych (statystyki?) niż strzeżenie praworządności (do czego zobowiązana jest przecież Prokuratura na mocy art. 64 ust. 1 Konstytucji Rzeczypospolitej Polskiej $\left.{ }^{16}\right)$.

3. Reasumując, bez wątpienia należy zaaprobować jasne stanowisko Sądu Najwyższego, zwłaszcza na tle zauważalnej w naszym kraju tendencji nie tylko do nadmiernie surowej/bezwzględnej realizacji funkcji ścigania karnego na podstawie przepisów Kodeksu karnego skarbowego, ale i do kryminalizacji czynów podatkowych w sytuacji, gdy w ogóle nie są to czyny podatkowe $\mathrm{w}$ rozumieniu prawa karnego skarbowego (sic!). Takie działania organów państwowych (organów ścigania) wcale nie służą umacnianiu poszanowania prawa ani zwiększaniu szacunku dla instytucji państwowych w naszym kraju. Wręcz przeciwnie, mogą nawet w konsekwencji spowodować bardzo niebezpieczne zjawisko, stan społeczny tzw. anomii (z gr. „bezprawie”), której istotą jest powstanie niespójności wewnątrz systemu aksjonormatywnego i niepewności co do obowiązywania prawa w całości lub w części. Niestety, pierwsze sygnały tego zjawiska już widać.

\section{BiBLIOGRAFIA}

Grzegorczyk T., Kodeks karny skarbowy. Komentarz, wyd. 4, Kraków 2009.

Kardas P., Łabuda G., Razowski T., Kodeks karny skarbowy. Komentarz, wyd. 3, Warszawa 2017.

Comments to the decision of the Supreme Court of January 15, 2021 (III KK 321/19, LEX NO. 3156190)

Summary. Commentary on the ruling of the Supreme Court concerning a criminal-fiscal act (k.k.s.), so-called failure to pay the tax collected on time by the payer (art. $77 \$ 1$ k.k.s.); the author approves the opinion of the Supreme Court confirming that the above-mentioned fiscal crime has the so-called material nature. Additionally, the author focuses on the problem of unjustified criminal prosecution in tax matters.

Keywords: taxes, fiscal penal code, failure to pay the tax collected on time by the payer, material nature of the fiscal crime

16 Konstytucja Rzeczypospolitej Polskiej z dnia 2 kwietnia 1997 r. (Dz.U. z 1997 r., Nr 78, poz. 483). 